\title{
"The status of quality management in selected Community Service Centres in the Western Cape, South Africa"
}

\begin{tabular}{|c|c|}
\hline AUTHORS & $\begin{array}{l}\text { Nicolette Daniels } \\
\text { Rozenda Hendrickse }\end{array}$ \\
\hline ARTICLE INFO & $\begin{array}{l}\text { Nicolette Daniels and Rozenda Hendrickse (2017). The status of quality } \\
\text { management in selected Community Service Centres in the Western Cape, } \\
\text { South Africa. Problems and Perspectives in Management, 15(2-2), 424-435. } \\
\text { doi:10.21511/ppm.15(2-2).2017.11 }\end{array}$ \\
\hline DOI & http://dx.doi.org/10.21511/ppm.15(2-2).2017.11 \\
\hline RELEASED ON & Monday, 04 September 2017 \\
\hline RECEIVED ON & Thursday, 30 June 2016 \\
\hline \multirow[t]{2}{*}{ ACCEPTED ON } & Monday, 27 February 2017 \\
\hline & $(\mathrm{cc}) \mathrm{EYY}-\mathrm{NC}$ \\
\hline LICENSE & $\begin{array}{l}\text { This work is licensed under a Creative Commons Attribution-NonCommercial } 4.0 \\
\text { International License }\end{array}$ \\
\hline JOURNAL & "Problems and Perspectives in Management" \\
\hline ISSN PRINT & $1727-7051$ \\
\hline ISSN ONLINE & $1810-5467$ \\
\hline PUBLISHER & LLC “Consulting Publishing Company "Business Perspectives" \\
\hline FOUNDER & LLC "Consulting Publishing Company "Business Perspectives" \\
\hline
\end{tabular}

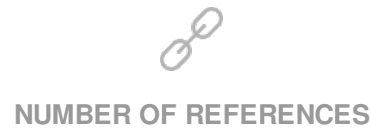

73
NUMBER OF FIGURES

0
NUMBER OF TABLES

3

(C) The author(s) 2023. This publication is an open access article. 


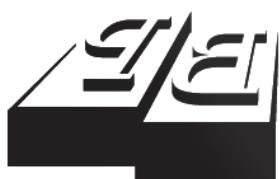

BUSINESS PERSPECTIVES

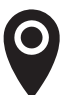

LLC "CPC "Business Perspectives" Hryhorii Skovoroda lane, 10, Sumy, 40022, Ukraine

www.businessperspectives.org

Received on: $30^{\text {th }}$ of June, 2016 Accepted on: $27^{\text {th }}$ of February, 2017

(c) Nicolette Daniels, Rozenda Hendrickse, 2017

Nicolette Daniels, Master of Technology, Public Management Graduate, Department of Public Administration and Governance, Cape Peninsula University of Technology, South Africa.

Rozenda Hendrickse, Associate Professor, Department of Public Administration and Governance, Cape Peninsula University of Technology, South Africa.

\section{(ㄷ)(1) $(8)$}

This is an Open Access article, distributed under the terms of the Creative Commons Attribution-NonCommercial 4.0 International license, which permits re-use, distribution, and reproduction, provided the materials aren't used for commercial purposes and the original work is properly cited.

\section{THE STATUS OF QUALITY MANAGEMENT IN SELECTED COMMUNITY SERVICE CENTRES IN THE WESTERN CAPE, SOUTH AFRICA}

\begin{abstract}
Quality management systems in public organizations influence the quality of service delivery outputs. The purpose of this study was to determine the quality of service delivery at Community Service Centres (CSC) of the South African Police Service (SAPS) in the Western Cape, South Africa. A mixed-method research approach was employed to gather data for the study. Both a survey questionnaire and in-depth interviews were used to collect the data. The sample data set contacted 300 respondents from three policing areas situated in the Western Cape Metropolis. The main findings indicated that clients were satisfied with the level of service they received from the SAPS. However, the main area of concern was the absence of service delivery initatives at three police stations.
\end{abstract}

Keywords

JEL Classification accountability, South African Police Service, Community Service Centres, quality services, quality management, service delivery

\section{INTRODUCTION}

The South African Police Service (SAPS) was formed in the 1990s through the integration of the South African Police with the police forces of ten ethnic homelands created under apartheid (apartheid in this context implies separate economic, political and social development of races). During apartheid, the South African police force was the principal instrument through which apartheid policies were enforced and maintained (Bruce, Newman, \& Masuku, 2007). With the rise of the "new" political dispensation, under the African National Congress, and the formulation of the "new" Constitution of the Republic of South Africa (Act 108 of 1996), a crucial re-assessment of the nature of policing in South Africa was required. SAPS needed to discard policies which contradicted the laws of the country. A charge office, at police stations, for example, was changed to Community Service Centre (CSC) which was in line with the new thinking around customer care. The term charge office/CSC denotes a front-line office manned by members of SAPS, 24 hours a day, 7 days a week, where clients are served (Zondi, 2012).

Clients are important stakeholders who must be brought into the strategic thinking of an organization. They are also seen as catalysts for change, so it is important to create and sustain a dialogue with them (Mofomme \& Barnes, 2004). Rashid (2008) notes that private sector organizations have adopted the principles of quality customer service at a much faster rate than those in the public sector. In the past, the public sector in South 
Africa had to a large extent escaped the scrutiny of and accountability to its clients (South African Police Service, 2013). However, entrenched in the Constitution is a commitment to improve the quality of life for all citizens in the country, which involves holding public servants accountable for the services they deliver to those citizens.

The aforementioned was confirmed by the promulgation of the White Paper on Transforming Public Service Delivery of 1997 (South Africa. Department of Public Service and Administration, 1997). The Batho Pele White Paper signalled very strongly government's intention to adopt a citizen-orientated approach to service delivery, informed by the eight principles of consultation, service standards, access, courtesy, information, openness and transparency, redress and value for money. The main objective of the Batho Pele principles on Service Delivery is to help improve public service delivery by supporting the transformation of the public service into a citizen-oriented organization (South Africa. Department of Public Service and Administration, 2007). The South African Police Service Act (Act 68 of 1995) declares SAPS to be a non-profit government organization with a responsibility to prevent, combat and investigate crime, maintain public order, protect and secure inhabitants of the country and their property, as well as to uphold and enforce the law. Therefore, SAPS needs to be accessible to every person and continuously strive to improve service delivery. SAPS would not exist without the customer, and SAPS must satisfy its customers to such a degree that they will return and advertise SAPS with pride.

Whisenand and Ferguson (1996) contend that quality and speed of service equate excellence. The authors are convinced that police managers and leaders are essential to the achievement of excellence. Consistency is vital, as aptly illustrated by Aristotle's quote: "We are what we repeatedly do. Excellence, then, is not an act, but a habit". As a service industry, SAPS is characterized by labor-intensive and intangible nature of its services, which cannot easily be displayed, demonstrated or communicated. Service delivery deals mainly with core functions and the support of those delivering core policing, and that outputs should be quantified and performance measured. Clients' needs should be determined, and, then, all available resources allocated in order to meet these needs effectively and efficiently (Reynecke \& Fourie, 2001).

In 2002, SAPS conducted an exit poll on CSCs in the Western Cape, and in comparison with the year 2001, SAPS scored a lower percentage in categories such as treating people with respect, trust in the police, safety of the CSCs, staff willingness to help; it seemed that most respondents wanted better service from their CSCs (South African Police Service, 2002). In 2009, SAPS introduced strategic leadership development and close performance monitoring for all levels of management. This led to the grouping of 148 police stations in the Western Cape into 25 provincial clusters. These clusters are the extension of the provincial office (South African Police Service, n.d.). Bruce, Newham, and Masuku (2007) reveal that this restructuring was based on in-depth reviews indicating that there were too many levels of authority, and that this was conducing to the duplication of functions, impeding effective command and controlling; and slowing delivery.

In light of the foregoing, the following research objectives were set.

\section{RESEARCH OBJECTIVES}

The core objective of the study was to establish whether the quality management systems that the South African government had put in place have been implemented at the 3 case study police stations. It further aimed to determine whether the public's expectations around quality service delivery were met.

\section{LITERATURE REVIEW}

\subsection{Legislative framework governing service delivery}

The legislative framework governing service delivery details the mechanisms through which government departments can attain their objectives and goals in delivering services to the public. It 
also ensures that government is transparent in respect of the processes of providing services and remains accountable to the people. The Constitution is the foundation on which all other legislation is built, and such legislation has to comply with its requirements. The South African Police Service Act (Act 68 of 1995) provides guidance for the effective operation of a police service, from administration duties to the conduct of police men and women. The Act also spells out the duties of all employed by the department, as well as the establishment of community police forums. The main objective of the Public Service Act (Act 103 of 1994), hereafter referred to as the Public Service Act, is to supply the public service with regulations for the establishment, administration, conditions of employment, terms of office, discipline, retirement and discharge for members of the public service and all other matters associated therewith (South Africa, 1994, p. 1). This Public Service Act is the foundation for administration and conduct within the public service and provides rules to which every government department must adhere.

Chapter 2 of the Public Service Regulations of 1999, emanating from the Public Service Act, forwards a Code of Conduct for public officials. The Code guides all public servants around their conduct as individuals, and in their relationships with others. In essence, the Code is a regulatory mechanism which ensures accountability on the part of public officials in every dimension of their employment mandate. This can also be seen as a principle for establishing good governance.

Every police official signs a formal Code of Conduct which was introduced in October 1997. It is a written undertaking indicating that each member of SAPS has to act in accordance with the law and constitutional principles (Institute for Security Studies, n.d.). The Code of Ethics demands that all employees of SAPS act with integrity and respect for people's diversity and the law, thus enriching service excellence to the approval of the public (Institute for Security Studies, n.d.). This should enhance service excellence to the approval of the public (SAPS, 2013).

“The Batho Pele principles signalled government's intention to adopt a citizen-orientated approach to service delivery, informed by the eight principles of consultation, service standards, access, courtesy, information, openness and transparency, redress and value for money as indicated before. The broad objective of the Batho Pele Principles on Service Delivery is to improve public service delivery by supporting the transformation of the public service into a citizen-orientated organization" (South Africa. Department of Public Service and Administration, 2007). According to Du Toit and Van der Walt (1999), the existence of any institution is directly linked to its purpose. Through providing such services, public institutions aim to improve the general welfare of society. The delivery of services is therefore the overall responsibility of government departments (Dorasamy, 2010).

Accountability is an amorphous concept which is not easy to define in precise terms. It involves two distinct aspects, answerability and enforcement, where answerability refers to the obligation of the government, its agencies and public officials, and enforcement suggests that the public or the institution responsible for accountability can sanction the offending party or remedy the contravening behavior (Adejuwon, 2012). The relationship between SAPS and the public is very delicate in nature, and it takes only one individual to tarnish the image of the entire organization. Commitment to quality client service must become an ongoing challenge to every individual within SAPS (SAPS, Division: Training, 2006). Successful service outcomes depend on government departments working with citizens to design, implement and evaluate services, with each party holding the other accountable in order to achieve better outcomes and continually learn from experience (The World Bank, 2011). The Western Cape was found to have made significant strides in implementing many of the Batho Pele principles, despite only being assigned the "redress" principle. It means that SAPS Western Cape takes into account the fact that access to services is a basic right for all communities. In the Service Delivery Improvement Plan, SAPS Western Cape committed itself to service excellence through the application of the Batho Pele principles (SAPS, 2013).

\subsection{Quality services}

Whisenand and Ferguson (1996, pp. 4-5) emphasize that top quality work requires dedication and careful attention to the quality of people in a de- 
partment or work unit. Meeting clients' expectations defines the concept of quality (clients here referring to both internal and external role players). Quality implies that the control of work requires continuous awareness and a conscious effort to maintain and improve quality service delivery. A service therefore refers to deeds, processes and performances, and includes all economic activities related to output. A service is generally consumed at the time it is produced and provides added value in many forms, including comfort, timeliness, convenience and amusement (Wilson, Zeithaml, Bitner, \& Gremler, 2008).

\subsection{Prerequisites for quality service}

Jon-Pape (2013) proposes a list of 5 determinants for quality service: tangibles, reliability, responsiveness, assurance and empathy. Tangibles involves the physical assets that an organization utilizes and positions the organization against their competitors. Reliability refers to performance in terms of which a customer service organization is only as good as the quality of service they provide. Responsiveness should be a top priority of a customer service company. Measurable goals should be set pertaining to customer responsiveness. Assurance entails the amount of confidence a customer service company instills in the client. Empathy involves understanding the customer's needs and responding in an appropriate manner. Training employees can assist in eradicating problems and will be discussed in the next section.

\subsection{The importance of training and motivating employees}

Training and commitment are two main culprits in stealing quality away from police work. Police officers are trained to be efficient, but without a full commitment to actually satisfying a customer's real needs, how can quality enter into the picture? (Whisenand \& Ferguson, 1996). Police training is important to both police commanders and personnel. Commanders need to feel confident that their officers know the fundamentals of the job. A lack of on-the-job training in fundamental skills such as these can be dangerous, since police officers often deal with people in highly volatile situations (Thibault, Linch, \& Mcbride, 1998). Training and education take a number of forms for staff, and include mentoring, on-the-job training, reading textbooks or manuals, group problem solving and short courses (Swarbrooke, 2002).

\subsection{Basic police academy training}

Bayley and Bittner, as quoted in Dantzker (1997), point out that the training given at police academies is universally regarded as irrelevant to real police work. Champion and Rush (1997) concur that "what they train you to do at the academy and what you really do here on the street" differs. Police academy training must emphasize community service as opposed to the traditional reducing crime approach. Reynecke and Fourie (2001) observe that the need for a fresh training and development approach is obvious as SAPS has to provide training for thousands of under-trained members, as well as deal with the orientation of its members to the new policing paradigm in South Africa. In an organization such as SAPS, which requires very specific knowledge, skills and attitudes from its members, it is the responsibility of the organization to ensure that opportunities to acquire these exist (Foster, 2004).

During 2002, SAPS head office training department was restructured. This led to the transformation of the Paarl College in the Cape, into the SAPS Management and Leadership Development Institute, Paarl. During 2013, a partnership between the Department of Police and the University of South Africa was announced. SAPS Academy Paarl has played a major role in restoring the dignity which would allow SAPS to transform into a professional organization with employees of integrity (Phakathi, 2013). The SAPS Academy Paarl would offer a Bachelor of Police Science Degree and leadership and management programes (SAPS, 2015).

\subsection{A quality management system}

The achievement, maintenance and enhancement of quality depend on establishing an organizational culture that puts quality first. A quality management system is concerned with assuring and maximizing quality now and in the future (SAQA, 2001). The South African Police Service (2013) asserts that the reality of quality lies in an understanding at all levels in the organization that poor quality always costs more than good quality. Poor quality performance could even result in people losing their lives, 
for which no cost can compensate. Ultimately, all taxpayers foot the bill for poor quality. In recent years, quality management systems have been introduced into service-orientated organizations such as financial institutions, medical facilities, training providers and government. For example, the South African Revenue Service has become more effective since the introduction of a quality management system that included changes in their operations, such as extended office hours, internet tax returns, call centres and information brochures (SAPS, 2013).

\subsection{Total quality management}

Thibault et al. (1995) provide some historical background to management in the police, describing the way management systems have evolved over time, from traditional, scientific, behavioral to proactive management, which incorporates many different schools of theory, one being the Total Quality Management Model, hereafter referred to as TQM, which is currently applied to police operations. TQM is defined as a strategic, integrated management system for achieving customer satisfaction, involving all managers and employees and using human resources, managerial and quantitative methods to continually improve organizational processes (Thibault et al., 1995).

\subsection{Police station management}

According to Fox, Van Wyk, and Fourie (1998), police management is a complex matter and sensitive to the environment in which management takes place. In 2012, the Resource Allocation Guide of police stations was reviewed and was approved in 2012 (Mhkwanazi, 2012). The revised structures within SAPS reflect the view of Reynecke and Fourie (2001) that it is important for logistics, financial services, human resources and information support, to be in synergy with operational services in order to provide an effective service to customers. Being a proficient manager requires leadership skills. A leadership system will be discussed in the next section.

\subsection{A leadership system}

According to Bittel and Newstrom (1990), leadership is defined as the knack of getting other people to follow you and to do willingly the things that you want them to do. To be a successful leader of subordinates, public managers must display and be aware of certain leadership characteristics. They must have the necessary ability to influence the behavior of subordinates (Du Toit \& Van der Waldt, 1997). Although writers frequently use the two terms synonymously, there is a distinction to be made between managers and leaders. Managers are appointed; they are granted legitimate power that allows them to reward and punish. In contrast, leaders may either be appointed or may emerge from within a group. Leaders can influence others to perform beyond the actions dictated by formal authority (DeCenzo \& Robbins, 2004). In SAPS, an authoritarian system of management has survived from the apartheid years into the new democracy. To be effective, leadership has to be seen and is best seen in action (Anderson, 2000).

\subsection{Community service centres of police stations}

Customers expect front-line personnel to know about their organization's products and services and provide customers with professional help (Silvestro, 2005). Front-line service employees are the only people who can access internal service quality (Lai, 2006). Therefore, the CSC focuses on administrative interaction with customers (Mkhwanazi, 2012). SAPS is governed by Standing Orders. "Standing Orders" (SO) means Standing or Force Orders, issued in terms of Regulation 6 of the Regulations for SAPS, promulgated by the Government Gazette Notice 79 R203 of 1964, as amended. Standing Order 28 as amended lists the many duties of a Station Commander. The following are only a few of the duties for which Station Commanders are held accountable, which includes the CSC of police stations:

- Station Commanders must manage the rendering of all policing services at CSC and the related duties to ensure effective client satisfaction service delivery.

- Station Commanders must also ensure that immediate steps are taken to prevent and to rectify any mistake, neglect of duty, lack of diligence or initiative, misconduct or incompetence on the part of any of their subordinates. 
- Station Commanders must always lead by example in rendering a policing service to the community (South Africa, 1964).

In January 2015, SAPS compiled a front-line service delivery project. Only one police station from each province was selected as a sample for this project. The project roll out plan, which will extend the project to all police stations in the country, is expected to be completed during 2018/2019. The overall goal of the project is to establish an effective, efficient, professional and accountable service delivery capability, to ensure that all people in South Africa are, and feel, safe (Mathonsi, 2015).

\subsection{Work performance}

Organizations are lifeless entities that require the enlivening presence of human resources to implement plans and strategies to make things happen. The process of making things happen is called performance. Performance must be managed to ensure that the objectives of the organization are attained. A system is needed that will enable management to determine whether the work is progressing as planned. This is known as control (Du Toit \& Van der Waldt, 1997). Control has an emotive connotation when it is interpreted in a negative manner to suggest direction or command by the giving of orders. The effectiveness of a control system is determined by how well it facilitates goal achievement (DeCenzo \& Robbins, 2004). Du Toit and Van der Waldt (1997) explain that setting performance standards provides a norm for measuring actual performance and enables performance management to motivate personnel to perform better. Holloway (2009) points out that effective performance management requires effective overall management, a key component of which is building relationships across organizational boundaries. In sum, for an organization to function at optimum level, managing individual and organizational performance efficiently and effectively is imperative (Phillips \& Hendrickse, 2013).

\subsection{Continuous improvement}

Fox et al. (1998) hold that station managers have to manage public and human resources in an ever-changing environment. Many factors influ- ence employee behavior: family life, unforeseen personal events, mental outlook, to name but a few. Feedback on employee performance is vital and has advantages such as enhancing employees' motivation (DeCenzo \& Robbins, 2004). Oakland (2000) argues that continuous improvement is probably the most powerful concept to guide management. The South African Police Service (2013) indicates that continuous improvement involves an approach of improving performance through small, incremental steps. An example would be modifying the way you talk to a customer in the CSC, simplifying the question sequence when taking a statement. Never-ending improvement is the process by which greater customer satisfaction is achieved. Its adoption recognizes that quality is a moving target, but its operation actually results in quality (Oakland, 2000).

\subsection{Community policing}

"Community-oriented policing has its antecedents in the early 1900s, before the advent of motor vehicles. Police officials either rode horses or walked through neighborhoods" (Champion \& Rush, 1997). Fox et al. (1998) notes that the interim Constitution, Act 221 of 1993, made provision for the establishment of CPFs and elaborated on their function, and that the speeches of politicians, policy documents and the South African Police Service Act, Act 68 of 1995, further endorsed community policing. In a nutshell, community policing was introduced as a mechanism to assist the SAPS in reducing crime, and CPFs were established in order to maintain a partnership between SAPS and the community in which they serve. Meyer and van Graan (2011) maintain that partnerships with local organizations and the business community should be formed in order to build capacity and consolidate resources.

\subsection{Measuring service quality}

Customer satisfaction is the outcome felt by those for whom a company's performance has fulfilled their expectations. Therefore, it is imperative to measure the type of service being provided in order to improve the service of any organization (Angelova \& Zekiri, 2016). Non-profit organizations attempt to achieve objectives other than profit. This does not mean that they are uninterested 
in income as they have to generate cash to survive. However, their primary goal is non-economic, for example, to provide cultural enrichment, protect endangered species, provide education, provide safety and security or supply healthcare (Jobber, 2007). Much of the research to date has focused on measuring service quality by using the Servqual instrument (Kang \& James, 2004). The Servqual instrument is a useful starting point, though not a final answer to assessing service quality. It does enable an organization to compare customer expectations and perceptions over time. It can be also used to categorize a company's customers into perceived quality segments on the basis of their individual Servqual score (Baron \& Harris, 2003).

\subsection{Service quality gaps}

Parasuraman, Zeithaml, and Berry (1985) claim that a set of key discrepancies or gaps exist regarding executive perceptions of service delivery quality and the tasks associated with service delivery to consumers. These gaps can be major hurdles in attempting to deliver a service which consumers would perceive as being of high quality.

\section{Gap 1. Consumer expectation - management perception gap}

The "management perception gap" refers to the divergence between the perceptions of customers and management with respect to what constitutes quality in service (Mahesh, 1993). Many organisations do not meet customer expectations because they fail to understand what those expectations are (Silvestro, 2005). The most critical step in delivering service quality is probably determining exactly what the customers need (Bennett, 2000). Service firms may not always understand what features a service must have in order to meet consumers' needs. This affects the way consumers evaluate service quality (Daniel \& Berinyuy, 2010).

\section{Gap 2. Management perception - service quality specification gap}

Daniel and Berinyuy (2010) argue that the service quality specification gap arises when a company identifies what the consumers want, but lacks the means to meet these expectations. This could be a result of inadequate commitment to service quality, a perception of unfeasibility, inadequate task standardisation or an absence of goal setting (Shahin \& Janatyan, 2011).

\subsubsection{Gap 3. Service quality specifications - service delivery gap}

This gap is also affected as a result of role ambiguity and conflict, poor employee placement and poor technology or job design, inappropriate supervisory control systems, lack of perceived control and lack of teamwork (Shahin \& Janatyan, 2011). The gap arises from a shortage of resources in key areas, such as lack of commitment and motivation, inadequate quality control procedures and inadequate staff training (McDaniel, Lamb, \& Hair, 2008).

\section{Gap 4. Service delivery - external communications gap}

External communication can affect not only consumer expectations of service, but also consumer perceptions of the delivered service (Daniel \& Berinyuy, 2010). Companies can neglect to inform consumers of special efforts to assure quality that are not visible to them, and this could influence service quality perceptions by consumers. This gap also arises as a result of inadequate horizontal communication and a propensity to over-compromize (Shahin \& Janatyan, 2011).

\section{Gap 5. Customers' expectations - perceptions of quality service gap}

As a result of influences exerted from the customer side and gaps on the part of the service provider, customer expectations are influenced by personal needs, word-of-mouth recommendation and past service experiences (Shahin \& Janatyan, 2011). The key to ensuring good service quality is meeting or exceeding what consumers expect from the service (Daniel \& Berinyuy, 2010).

\section{RESEARCH METHODOLOGY}

This study followed a mixed method research approach. Quantitative data were collected by means of a survey, and qualitative data were collected via interviews. 


\subsection{Research participants}

Quantitative data collection: the combined target population of the three participating police stations was 1500 . A sample size of 300 respondents was determined to be adequate for the purpose of the test. There are no demographic descriptions of the respondents, as it is irrelevant in terms of service delivery. The only requisite was that respondents had to be 18 years of age or older. Convenience sampling was used, as it allowed the researcher to survey participants who were available at particular times in the CSCs. The sample selection process was continued until the required sample size was reached (Welman et al., 2005, p. 69). The 300 clients identified as the sample consisted of 100 clients from each policing area.

Qualitative data collection: a secondary population was constituted by the three Station Commanders of the identified police stations and their senior, the Deputy Provincial Commissioner.

\subsection{Measuring instruments}

A structured questionnaire targeted at clients who entered the Community Service Centres of the identified police stations was utilized in order for the statistical data to be easily analyzed. The structured questionnaire was developed based on the Servqual model for measuring service quality. Unstructured interviews were conducted with the three Station Commanders of the police stations, as well as with their senior, the Deputy Provincial Commissioner: operations of the SAPS, as mentioned before. A set of two unstructured interview schedules were developed to guide the researcher during the interviews. One interview schedule was administered to the Station Commanders of the selected police stations, and the other to their provincial senior, the Acting Deputy Provincial Commissioner.

\subsection{Research procedure}

The Cape Peninsula University of Technology's inhouse statistician assisted in compiling the structured questionnaire. An outline of the purpose of the study, the importance of completing the questionnaire, as well as the procedures for completing the questionnaire was explained to the participants in a cover letter. The questionnaire was administered by one the researchers and a research assistant. Interviews were held face-to-face for the convenience of the identified participants.

\subsection{Statistical analysis}

Quantitative data was analyzed using the Statistical Package for Social Sciences (SPSS) software.

\subsection{Content analysis}

In this study content analysis was applied to make sense of the qualitative data collected by way of the in-depth interviews. The aim of the interviews was to determine if there were set patterns of service delivery at the police stations selected.

\section{RESULTS}

The study, examined whether governmental systems designed to enhance service delivery, such as the Batho Pele principles and the Codes of Conduct and Ethics for police officials, were being executed. This objective also tested whether management had accurately determined the standards that clients required and whether the standard was being delivered.

The survey revealed that the majority of respondents were of the opinion that the service they received was of an acceptable standard. Although the majority of the feedback can be seen as positive there is still scope for improvement. This result

Table 1. Services rendered by this CSC were of an acceptable standard

\begin{tabular}{|c|c|c|c|c|c|}
\hline & & Frequency & Percent & Valid percent & Cumulative percent \\
\hline \multirow{6}{*}{ Valid } & Strongly disagree & 4 & 1.3 & 1.3 & 1.3 \\
\hline & Disagree & 28 & 9.3 & 9.3 & 10.7 \\
\hline & Neutral & 10 & 3.3 & 3.3 & 14.0 \\
\hline & Agree & 186 & 62.0 & 62.0 & 76.0 \\
\hline & Strongly agree & 72 & 24.0 & 24.0 & 100.0 \\
\hline & Total & 300 & 100.0 & 100.0 & \\
\hline
\end{tabular}


Table 2. CSC personnel took all needs into consideration in terms of service delivery

\begin{tabular}{l|c|c|c|c}
\hline & Frequency & Percent & Valid percent & $\begin{array}{c}\text { Cumulative } \\
\text { percent }\end{array}$ \\
\hline Strongly disagree & 7 & 2.3 & 2.3 & 2.3 \\
\hline Disagree & 36 & 12.0 & 12.0 & 14.3 \\
\hline Neutral & 32 & 10.7 & 10.7 & 25.0 \\
\hline Agree & 136 & 45.3 & 45.3 & 70.3 \\
\hline Strongly agree & 89 & 29.7 & 29.7 & 100.0 \\
\hline Total & 300 & 100.0 & 100.0 & \\
\hline
\end{tabular}

Table 3. Service delivery or awareness campaigns have had a positive impact on views of SAPS

\begin{tabular}{|c|c|c|c|c|c|}
\hline & & Frequency & Percent & Valid percent & $\begin{array}{c}\text { Cumulative } \\
\text { percent }\end{array}$ \\
\hline \multirow{6}{*}{ Valid } & Strongly disagree & 143 & 47.7 & 47.7 & 47.7 \\
\hline & Disagree & 35 & 11.7 & 11.7 & 59.3 \\
\hline & Neutral & 69 & 23.0 & 23.0 & 82.3 \\
\hline & Agree & 40 & 13.3 & 13.3 & 95.7 \\
\hline & Strongly agree & 13 & 4.3 & 4.3 & 100.0 \\
\hline & Total & 300 & 100.0 & 100.0 & \\
\hline
\end{tabular}

linked to the responses from the in-depth interviews held with the participants who believed that in delivering quality services, it was imperative to give your best to all your clients, as well as their communities. This indicates that there are systems in place at these police stations to address service delivery issues. However, if these systems were working flawlessly, there should have been fewer respondents who disagreed or who remained neutral with certain statements in the survey.

The findings indicated that clients were generally satisfied with the quality of services they received, and that their needs were being met. A small number of clients were dissatisfied. The dissatisfied clients provide an opportunity for improvement on service delivery.
The study aimed to uncover whether police stations had service delivery initiatives; if they were ongoing, what sort of impact they had on clients, and whether police stations were held to account for the services they delivered. Keeping in mind that the client is the most important person in the organization, the findings of this portion of the research are of utmost importance. The respondents in this instance indicated that SAPS was deficient in this area of service delivery. The final research objective aimed to provide possible solutions to identified gaps which existed in relation to quality management, and to determine how service delivery in the CSC of police stations could continuously be improved. The findings in regard to the last objective are therefore linked to the recommendations made.

\section{RECOMMENDATIONS}

To ensure continuous improvement within SAPS, all levels of management, irrespective of their rank, should have their skill sets developed in their area of expertise. A team or committee consisting of various role players, who work in CSC should compile a checklist on problematic areas in quality management in general. The selected team should be equipped with detailed knowledge of what quality service entails in order to implement processes to address specific problem areas, with special emphasis on the CSC of their police station, and their clients' needs.

Defined measurable service quality and client satisfaction goals should be developed by the provincial strategic management component, in order to assess the level of quality management at police stations. 
Senior managers on a provincial and national level should implement bi-annual reviews of the planning and execution of quality management systems, so as to report on their suitability, adequacy and effectiveness to the provincial management structures of SAPS.

The Station Commander in conjunction with their station's Sector Commanders and CPF should orchestrate service delivery awareness initiatives, such as pamphlet distribution, at their police stations, and in every sector of the community that they serve, in order to close any gaps which might exist in terms of service delivery to the community. The Station Commander and his or her management structures should establish an action committee which meets monthly in order to plan for change in areas that are problematic, as well as to correlate and create effective strategies when the budget is released, in order to maximize improvement on service delivery to their community.

\section{CONCLUSION}

Managers in SAPS should improve on their efficiency and effectiveness in the way in which services are delivered in order to attain customer satisfaction. SAPS has also taken cognisance of the problematic areas which requires interventions in terms of the Batho Pele principles. The community is a pivotal role player, and if they participate and assist the police, a strong partnership can be created. Measuring service to clients would assist SAPS in identifying gaps in service delivery in order to eliminate such, with the aim to achieve mutual satisfaction for the organisation as well as its customers. The main area of concern was the absence of service delivery initatives conducted at the selected police stations. The interviews held with police managers indicated that management recognizes the importance of quality, and that quality service had to be provided in order to satisify customers.

\section{ACKNOWLEDGEMENTS}

Competing interests. The authors declare that they had no financial or personal relationships that may have inappropriately influenced them in writing this article.

Authors' contributions. Ms. Nicolette Daniels was responsible for the formulation of literature review, methodology and reporting of the results. Professor Rozenda Hendrickse supervised the overall research project.

\section{REFERENCES}

1. Adejuwon, K. (2012). The dilemma of accountability and good governance for improved public service delivery in Nigeria. Africa's Public Service Delivery and Performance Review, 1(3), 25-45, December.

2. Anderson, T. (2000). Every officer is a leader: transforming leadership in police, justice and public safety. London: St. Lucie Press.

3. Angelova, B., \& Zekiri, J. (2016). Measuring customer satisfaction with service quality using American customer satisfaction.
International Journal of Service Industry Management, 27(2), 232-258.

4. Bittel, L., \& Newstrom, J. (1990). What every supervisor should know (6th ed.). Singapore: McGraw-Hill.

5. Bruce, D., Newham, G., \& Masuku, T. (2007). In service of the people's democracy, an assessment of the South African Police Service. Retrieved from http://www.csvr. org.za (accessed on 4 May 2015).

6. Champion, D., \& Rush, G. (1997). Policing in the community. New Jersey: Prentice-Hall.
7. Code of Conduct for Public Servants-Public Service Commission. (1999). Retrieved from www.psc.gov.za (accessed on 30 August 2015).

8. Daniel, C., \& Berinyuy, L. (2010). Using the servqual model to assess service quality and customer satisfaction. Unpublished Master's thesis, UMEA University.

9. Dantzker, M. L. (1997). Contemporary policing: personnel, issues and trends. Newton: Butterworth-Heinemann. 
10. Decenzo, D., \& Robbins, S. (2004). Fundamentals of management: essential concepts and applications (4th ed.). New Jersey: Pearson Prentice Hall.

11. Delport, C. S. L., de Vos, A. S., Strydom, H., \& Fouché, C. B. (2002). Research at grass roots: for the social sciences and human service professions (2nd ed.). Pretoria: Van Schaik.

12. Delport, C. S. L. de Vos, A. S., Strydom, H., \& Fouché, C. B. (2011). Research at grass roots: for the social sciences and human service professions (4th ed.). Pretoria: Van Schaik.

13. Dorasamy, N. (2010). Enhancing ethical culture through purposedirected leadership for improved public service delivery: a case for South Africa. African Journal of Business Management, 4(1), 56-64, January.

14. Du Toit, D. F. P., \& van der Waldt, G. (1997). Managing for excellence in the public sector. Kenwyn: Juta \& Co.

15. Du Toit, D. F. P., \& van der Waldt, G. (1999). Public administration and management: the grassroots. Kenwyn: Juta \& Co.

16. Foster, S. T. (2004). Managing quality: an integrative approach (2nd ed.). New Jersey: Person Education Inc.

17. Fox, W., van Wyk, B., \& Fourie, M. (1998). Police management in South Africa. Cape Town: Juta \& Co.

18. Holloway, J. (2009). Performance management from multiple perspectives: taking stock. International Journal of Productivity and Performance Management, 58(4), 391-399.

19. Institute for Security Studies. n.d. Code of Conduct for police officials. Retrieved from http:// www.issafrica.org/crimehub/policing (accessed on 15 May 2015).

20. Institute for Security Studies. n.d. Code of Ethics for the South African Police Service. Retrieved from http://www.issafrica.org/ crimehub/policing (accessed on 15 May 2015).
21. Institute for Security Studies. n.d. Code of Conduct for police officials. Retrieved from http:// www.issafrica.org/crimehub/policing (accessed on 15 May 2015).

22. Jobber, D. (2007). Principles and practice of marketing (5th ed.). Bradford: McGraw-Hill.

23. Johnson, R., \& Onwuegbuzie, A. (2004). Mixed methods research: a research paradigm whose time has come. American Educational Research Association, 33(7), 14-26, October.

24. Jon-Pape. (2013). Five determinants of quality service. Retrieved from http://www. jon-pape.com/5-determinants-ofquality-service (accessed on 3 July 2015).

25. Kang, G., \& James, J. (2004). Service quality dimensions: an examination of Gronroos's service quality model. Journal of Service Theory and Practice, 14(4), 266277, August.

26. Lai, J. Y. (2006). Assessment of employees' perception of service quality dimensions on behavioural purchase intention: a study in public sector transport. Managing Service Quality, 17(2), 134-151.

27. Lovelock, C., \& Wright, L. (2002). Principles of service marketing and management (2nd ed.). Upper Saddle River: Pearson education.

28. Lovelock, C., \& Wirzt, J. (2007). Service marketing: people, technology, strategy (6th ed.). Upper Saddle River: Pearson Prentice-Hall.

29. Lunenberg, F. (2010). Formal communication channels: upward, downward, horizontal and external. National Forum Journals, 4(1), 1-7.

30. Mahesh, V. S. (1993). Human resource planning and development: a focus on service excellence. In T. Baum (Ed.), Human resource issues in international tourism. Oxford: Butterworth-Heinemann.

31. Mathonsi, T. (2015). Front-line service delivery project of the South African Police Service, 30 January.
32. Meyer, M., \& van Graan, J. (2011). Effective community policing in practice: the Roodekrans neighbourwood watch case study, West Rand. South African Journal of Criminology, 24(2), 130-143.

33. Mitra, A. (1998). Fundamentals of quality control and improvement (2nd ed.). London: Prentice-Hall.

34. Mkhwanazi, N. (2012). Letter to the Deputy, Divisional and Provincial Commissioners of the South African Police Service, 29 February.

35. Mofomme, L., \& Barnes, N. (2004) An investigation into the quality of service delivered by the South African Police Service in the North Rand, Gauteng. Department of Human Resource Management, Rand Afrikaans University, 2(2), 11-16, July.

36. Mothiba, L. (2012) December. Letter to the Provincial Commissioners of the South African Police Service.

37. Oakland, J. (2000). Total quality management: text with cases (2nd ed.). Oxford: Butterworth Heinemann.

38. Parasuraman, A., Zeithaml, V., \& Berry, L. (1985). A conceptual model of service quality and its implications for future research. The Journal of Marketing, 49(4), 41-50.

39. Parasuraman, A., Zeithaml, V., \& Berry, L. (1988). SERVQUAL: a multiple-item scale for measuring consumer perceptions of service quality. Journal of Retailing, 64(1), 12-40.

40. Phakathi, B. (2013). SAPS, Unisa agree to create police university. Retrieved from http://www.bdlive. co.za (accessed on 24 August 2015).

41. Phillips, S., \& Hendrickse, R. (2013). The balance scoreboard performance management system communication process. Administratio Publica, 21(3), 20-40.

42. Public Service Regulations of 1999. Department of Public Service and Administration. Retrieved from http://www.dpsa.gov.za (accessed on 30 June 2015). 
43. Quality Management Systems for Education and training providers. (2001). Retrieved from http:// www.saqa.org.za (accessed on 15 July 2015).

44. Quality Management Systems (n.d). Retrieved from http://www. abahe.co.uk (accessed on 30 June 2015).

45. Rashid, M. (2008). Measuring and achieving customer service: a study on the public sector in Malaysia. Unpublished Master's thesis, Rochester Institute of Technology.

46. Rauch, J. (1992). South African police basic training: a preliminary assessment. Retrieved from http://www.csvr.org.za (accessed on 30 June 2015).

47. Rauch, J. (1992). A preliminary assessment of the impact of the peace accord code of conduct on police behavior. Retrieved from http://www.csvr.org.za (accessed on 30 June 2015).

48. Reynecke, F., \& Fourie, M. (2001). Police management beyond 2000. Cape Town: Juta and Co.

49. Service Charter. (2013). Service Charter. Retrieved from http:// www.dpsa.gov.za/servicecharter 2013.pdf (accessed on 22 June 2015).

50. Shahin, A., \& Janatyan, N. (2011). Estimation of customer dissatisfaction based on service quality gaps by correlation and regression analysis in a travel agency. International Journal of Business and Management, 6(3), 99-108.

51. Shillingford, A. (2006). Data collection protocols \& participatory research techniques: training of trainers manual.

52. Silverman, D. (2001). Interpreting qualitative data: methods for analyzing talk, text and interaction (2nd ed.). London: Sage publications.

53. Silvestro, R. (2005). Applying gap analysis in the healthy to inform the service improvement agenda. International Journal of Quality and Reliability Management, 22(3), 215-220.

54. South Africa. Department of Public Service and Administration. (1997). White Paper on Transforming Public Service Delivery. Pretoria: Government Printer.

55. South Africa. (1996). The Constitution of The Republic of South Africa, Act 108 of 1996. Pretoria: Government Printer.

56. South Africa. (1994). Public Service Act, No. 103 of 1994. Pretoria: Government Printer.

57. South Africa. The South African Police Service Act, Act 68 of 1995 Pretoria: Government Printer.

58. South Africa. (1964). Regulations for the South African Police Service. Notice 79 R2013 of 1964, as amended. Government Gazette, 79(R203), 1-7, February 14.

59. South Africa. (2007). Public Service Amendment Act of 2007. Government Gazette, 511(30675), 1-49.

60. South African Police Service, Division: Human Resource Development. (2013). Learner's guide: junior management learning programme: quality policing. Pretoria.

61. South African Police Service, Division: Training. (2006) Community Service Centre. Pretoria.

62. South African Police Service (n.d.). Western Cape Performance plan 2009/2010. Retrieved from https:// www.saps.gov.za/performance (accessed on 01 March 2015).

63. South African Police Service (n.d.). Careers. Retrieved from http:// intranet.saps.gov.za/hr/careers/job descriptions (accessed on 16 June 2015).

64. Swarbrooke, J. (2002). The development and management of visitor attractions (2nd ed.). Burlington: ButterworthHeinemann.

65. The World Bank (TWB) (2011). Accountability in public services in South Africa. Retrieved from http://www.worldbank.org.za (accessed on 30 June 2015).

66. Thibault, E., Lynch, L., \& McBride, R. (1995). Proactive police management (3rd ed.). New Jersey: Prentice-Hall.

67. Thibault, E., Lynch, L., \& McBride, R. (1998). Proactive police management (4th ed.). New Jersey: Prentice-Hall.

68. Welman, R., Kruger, S., \& Mitchell, B. (2005). Research Methodology (3rd ed.). Oxford: Oxford University Press.

69. Western Cape (South Africa). Department of Community Safety. (2012). Report on the Identification of Policing Needs and Priorities (PNPs 2011/2012). Cape Town: Department of Community Safety, Provincial Government of the Western Cape.

70. Western Cape (South Africa). Department of Community Safety. (2013). Report on the Identification of Policing Needs and Priorities (PNPs 2012/2013). Cape Town: Department of Community Safety, Provincial Government of the Western Cape.

71. Whisenand, P. M., \& Ferguson, R. F. (1996). The managing of police organizations (4th ed.). New Jersey: Prentice-Hall.

72. Wilson, A., Zeithaml, V. A., Bitner, M. J., \& Gremler, D. D. (2008). Service marketing: integrating customer focus across the firm. Maidenhead: McGraw-Hill.

73. Zondi, P. (2012). Service delivery and the South African Police Service Community Service Centres: an evaluative study of East Rand, Gauteng (Unpublished Master's thesis, Tshwane University of Technology). 